\title{
Harvesting peatland black spruce: Impacts on advance growth and site disturbance
}

\author{
by Marc R. MacDonell ${ }^{1}$ and Arthur Groot ${ }^{2}$
}

A project was established in the Lake Abitibi Model Forest to study the effects of several harvesting systems on advance growth protection and site disturbance. Tree-length and cut-tolength harvesting systems were compared to a full-tree system on peatland black spruce (Picea mariana (Mill.) B.S.P.) sites. The impacts of the various harvesting systems were compared by summarizing the structural and mensurational properties of the stands before and after harvest, by evaluating damage to residual trees, and by assessing site disturbance. The tree-length and full-tree systems, which were compared in winter harvesting, produced similar results. The cut-to-length system was compared to the fulltree system in both winter and summer harvesting, and protected substantially more advance growth, especially in the summer. Additionally, the cut-to-length system produced less damage to residual trees and lesser amounts of site disturbance. All harvesting systems resulted in or maintained residual stands with an unevensize structure.

Key words: black spruce, advanced regweneration, tree harvesting, systems
Un projet a été entrepris dans la forêt modèle de Lake Abitibi afin d'étudier les effets de certains systèmes de récolte sur la protection de la régéneration pré-établie et sur la perturbation du site. Des systèmes de récolte d'arbres en longueur et multi-fonctionnels ont été comparés à un système d'arbres entiers pour des stations d'épinette noire (Picea mariana (Mill.) B.S.P.) de tourbière. Les impacts des différents systèmes de récolte ont été comparés en résumant les propriétés structurelles et dendrométriques des peuplements avant et après la récolte, en évaluant les dommages occasionnés aux arbres résiduels, et en estimant la perturbation des stations. Les systèmes d'arbre en longueur et d'arbre entier, qui ont été comparés au cours d'une récolte hivernale, ont engendré des résultats similaires. Le système multi-fonctionnel a été comparé au système d'arbre en entier au cours d'une récolte hivernale et estivale; la protection de la régénération pré-établie était substantiellement plus importante selon le système multi-fonctionnel, surtout au cours de l'été. De plus, le système d'arbre en longueur a entraîné moins de blessure aux arbres résiduels et moins de perturbation de la station. Tous les systèmes ont engendré ou permis de maintenir des peuplements résiduels ayant une structure inéquienne.

Mots clés: épinette noire, régénération pré-établi, récolte d'arbre, systèmes

\section{Introduction}

Black spruce (Picea mariana (Mill.) B.S.P.) forests on peatlands often contain sufficient advance growth to form a well-regenerated stand immediately following forest harvesting (Groot 1984). Well-stocked black spruce stands, of advance growth origin, developed on peatlands after the manual harvest methods used in the first half of the century (Groot and Horton 1994). However, with the mechanization of harvesting in the 1950s and 1960s survival of advance growth was greatly reduced (Frisque et al. 1978), particularly by systems using the wheeled skidder. Nonetheless, efforts to protect advance growth using mechanized harvest systems continued. The term "careful logging around advance growth" (CLAAG) was applied in the late 1970 s by Spruce Falls Power and Paper Co., of Kapuskasing, ON (now Spruce Falls Inc.) to harvest operations in which advance growth protection was practiced (Jeglum et al. 1983). This expression is now frequently shortened to "careful logging". In Québec, a synonymous term is "coupe avec protection de la régénération"; i.e. harvest with protection of advance regeneration (Gingras 1990). During the past 10-20 years, considerable development and improvement was made in the ability of harvesting equipment and techniques to protect advance growth.

Department of Natural Resources Canada, Canadian Forest Service - Sault Ste. Marie, 1219 Queen St. E., Sault Ste. Marie, Ontario, Canada P6A 5M7. ${ }^{1}$ Current address: 14139 Kindersley Dr., Surrey, British Columbia, Canada V3R 5P6.

${ }^{2}$ Author to whom correspondence should be addressed.

In northeastern Ontario, protection of advance growth in peatland black spruce is currently practiced using the full-tree harvesting system, usually with a feller-buncher as the harvesting machine. However, a substantial proportion of advance growth is destroyed by this system. Site disturbance, in the form of deep ruts in organic soil, sometimes results from harvesting as well. Possibly, alternative harvesting systems are more effective at preserving advance growth (Gingras 1991), but little comparative data exists for peatland black spruce.

Consequently, a project was initiated in the Lake Abitibi Model Forest to test various harvesting equipment and techniques on peatland forest sites. Three harvesting systems (full-tree, cutto-length, and tree-length) were compared to determine postharvest black spruce advance growth levels, site disturbance, and the productivity and costs of the harvesting systems. The partners involved in the project were the Canadian Forest Service (CFS - Sault Ste. Marie), Abitibi-Price Inc. (API) of Iroquois Falls, ON, and the Forest Engineering Research Institute of Canada (FERIC).

This paper describes the biological aspects of careful logging and compares the impacts of the various harvesting systems by summarizing stand attributes before and after harvest, evaluating damage to residual trees, and assessing site disturbance.

\section{Methods \\ Study Area}

The study comprises two experiments: (i) full-tree versus cut-to-length and (ii) full-tree versus tree-length. The experimental sites are located in the Northern Clay Section of the Boreal Forest Region (Rowe 1972) in peatland, black spruce dominated stands. The sites were predominantly Forest 
Ecosystem Classification (FEC) Site Types 11 and 12 (Ledum and Alnus/herb poor) (McCarthy et al. 1994). The full-tree versus cut-to-length comparison was located about $90 \mathrm{~km}$ north $\left(49^{\circ} 37 \mathrm{~N}, 80^{\circ} 44^{\prime} \mathrm{W}\right)$ of the town of Iroquois Falls, Ontario. The stands at this site were over-mature and breaking up, with an uneven-sized structure. The pre-harvest density of trees $>1.3$ $\mathrm{m}$ in height averaged 3,367 stems ha-1 and basal area averaged $20 \mathrm{~m}^{2} \mathrm{ha}^{-1}$. Black spruce accounted for $90 \%$ of the stem density, balsam fir (Abies balsamea (L.) Mill.) $8 \%$ and tamarack (Larix laricina (Du Roi) K. Koch) $2 \%$. The height of the dominant trees was $19.5 \mathrm{~m}$, and merchantable volume averaged $98.2 \mathrm{~m}^{3} \mathrm{ha}^{-1}$. The mean density and stocking ( $4 \mathrm{~m}^{2}$ basis) of black spruce stems $<1.3 \mathrm{~m}$ in height was 26,437 stems ha- $^{-1}$ and $88 \%$, respectively. Density and stocking for balsam fir stems $<1.3 \mathrm{~m}$ in height were 2,620 stems ha $^{-1}$ and $21 \%$, respectively.

The full-tree versus tree-length comparison involved two sites: two replications were located in Stimson township $\left(49^{\circ} 03^{\prime} \mathrm{N}, 80^{\circ} 36^{\prime} \mathrm{W}\right), 32 \mathrm{~km}$ north of Iroquois Falls, and two replications were located in Mortimer township $\left(48^{\circ} 33^{\prime} \mathrm{N}\right.$, $\left.80^{\circ} 38^{\prime} \mathrm{W}\right), 17 \mathrm{~km}$ north of Iroquois Falls. The stands at these sites were uneven-sized, second-growth black spruce. The preharvest basal area averaged $23 \mathrm{~m}^{2} \mathrm{ha}^{-1}$ and the density of trees $>1.3 \mathrm{~m}$ in height averaged 3,833 stems ha $^{-1}$. Black spruce accounted for $82 \%$ of the stem density, while balsam fir and tamarack accounted for $17 \%$ and $1 \%$, respectively. The height of the dominant trees was $18 \mathrm{~m}$, and average merchantable volume was $104.5 \mathrm{~m}^{3} \mathrm{ha}^{-1}$. The average density of black spruce stems $<1.3 \mathrm{~m}$ tall was 13,465 stems $^{-1}$, and the mean stocking was $74 \%$. For balsam fir, the corresponding values were 12,550 stems $^{-1}$ and $63 \%$.

\section{Harvest Treatments}

At the full-tree versus cut-to-length study site, four harvest treatments were applied in a completely randomized design of three replications of 3.75 ha units $(250 \mathrm{~m} \times 150 \mathrm{~m})$ : (i) fulltree/winter, (ii) cut-to-length/winter. (iii) full-tree/summer, and (iv) cut-to-length/summer. The full-tree system comprised a Timberjack 618 feller-buncher with a continuously rotating circular saw head and a Timberjack Lokomo 933 clam-bunk skidder. The cut-to-length system comprised a Timberjack FMG 1270 single-grip harvester and a Timberjack FMG 1010 shortwood forwarder, with log lengths of $5.2 \mathrm{~m}$. The winter harvest occurred from January to March 1994, and the summer harvest occurred during August 1994.

During March of 1995, at the full-tree and tree-length comparison site, two harvest treatments were conducted in four paired replications of 3.75 ha units each: (i) full-tree/winter, and (ii) tree-length/winter. The equipment involved in the fulltree system was the same as in the full-tree versus cut-to-length comparison experiment. For the tree-length system, a John Deere 653E feller-buncher with an Ultimate Harvester felling head, and a John Deere 648E grapple skidder were used.

Harvest treatments were randomly assigned to harvest blocks. Black spruce and balsam fir were the only species harvested. Tamarack, an unmerchantable species in this region, was left standing. All merchantable trees $(>10-12 \mathrm{~cm}$ diameter at breast height $(\mathrm{DBH})$ ) were harvested, and machinery travel was restricted to narrow trails (about $7 \mathrm{~m}$ wide for full-tree, $4 \mathrm{~m}$ for cut-to-length, and 5-6 m for tree-length). Trail placement was at the operator's discretion, and with the cut-to-length equipment in particular, it was possible to protect larger clumps of black spruce advance growth by minor adjustments in the trail placement. The travel of the machines was parallel to the long axis of the block. Operators were instructed to avoid damaging the residual trees and advance growth by controlling the swing of booms, and by planning ahead of time where to travel, where to drop felled trees, and in the case of the cut-tolength system, where to process and pile the bucked lengths.

\section{Assessments}

In each experiment, the harvest blocks were assessed before harvest. Within each block, five transects were established, perpendicular to the planned direction of equipment travel, $40 \mathrm{~m}$ apart from one another. Each transect was divided into $402 \times 2$ m quadrats. Within each quadrat, the species and DBH were recorded for each tree $>1.3 \mathrm{~m}$ in height. As well, the species and height of all stems $<1.3 \mathrm{~m}$ in height and the percentage cover of alder were recorded.

One growing season after harvest, the transects were reassessed. The 1994 winter harvest was reassessed in August of 1994, and the 1994 summer and 1995 winter harvests were reassessed in August of 1995. For the residual trees $>1.3$ $\mathrm{m}$ in height, species and $\mathrm{DBH}$ were noted. A damage rating was given to each remaining tree; categories included undamaged, broken stem, broken top, sheared branches, scraped $(<1 / 2$ or $>1 / 2$ of the stem circumference), sun scorched, or multiple injuries. Stems $<1.3 \mathrm{~m}$ tall were reassessed as well; species, height, current annual height increment (CAHI) and a damage rating were recorded. The percentage of alder cover, slash cover, shallow rutting and deep rutting was also tallied. Ruts were classified as shallow when the peat soil surface was compressed, but maintained its integrity. Ruts were classified as deep when the more highly decomposed peat from lower soil layers was exposed.

At each harvest site, heights and diameters of black spruce with $\mathrm{DBH}>4 \mathrm{~cm}$ were sampled to develop a height-diameter relationship for local volume equations. A minimum of three trees per 2-cm diameter class were measured.

\section{Data Analyses}

For trees $>1.3 \mathrm{~m}$ in height, pre- and post-harvest density, basal area, total volume and merchantable volume were calculated for all conifer species together. Density was divided into small trees $(\leq 10 \mathrm{~cm}$ DBH$)$, large trees $(>10 \mathrm{~cm} \mathrm{DBH})$ and total trees. The post-harvest to pre-harvest ratio for each variable was also calculated. Pre-harvest and post-harvest diameter distributions (in 2-cm classes) were determined for each harvesting system.

Honer's volume equations (Honer et al. 1983), using an adjusted squared diameter ratio, were utilized to calculate total and merchantable volumes. Honer's equations were modified according to Maurer (1993), where the height variable is replaced with the local equation expressing height as a function of diameter.

Due to small numbers in some of the damage categories, broken top and broken stem were combined into broken stem/top, and scraped ( $<0.5$ of the stem) and scraped ( $>0.5$ of the stem) were added together to form scraped stems. Percentages were calculated for each category.

Statistical analysis was performed, using the NCSS statistical package (Hintze 1995), on the harvest block means of all the pre- and post-harvest variables and their ratios. For the full- 
tree versus cut-to-length comparison, a two-way analysis of variance (ANOVA) with $\alpha=0.05$ was applied with harvest system and season as the fixed effect variables. The assumption of equality of variance among groups was examined using the modified Levene test, and the assumption of normality was examined using D'Agostino tests of skewness and kurtosis (Hintze 1995). In cases where any of these assumptions could not be accepted $(P<0.05)$, transformations were applied to equalize variances or normalize residuals. These transformations included $x^{2}, x^{0.5}$, and $\log (x)$. Transformations were unsuccessful for four variables, and for these, the MannWhitney U test (Hintze 1995) was used to detect differences in ranks between harvest methods and seasons.

A paired $t$-test with $\alpha=0.05$ was used to compare the fulltree versus tree-length systems.

\section{Results}

\section{Full-tree versus Cut-to-length}

\section{Diameter Distribution}

Prior to harvest, all blocks exhibited an inverse J-shaped diameter distribution, with high stem densities in the lower diameter classes gradually decreasing to low densities in the higher classes (Fig. 1). Following both the winter and summer harvest, the density of trees $\geq 14 \mathrm{~cm} \mathrm{DBH}$ was nearly zero, but the inverse $\mathrm{J}$-shaped distribution persisted. The greatest change from the preharvest diameter distribution occurred after summer fulltree harvesting.

\section{Residual Trees $>1.3 \mathrm{~m}$ Tall}

There were no significant differences among harvest treatments in the pre-harvest densities of all conifer species, except that large trees $(>10 \mathrm{~cm} \mathrm{DBH})$ were more numerous in the full-tree than in the cut-to-length blocks (Table 1). This difference did not persist after harvest, however, and there was evidence $(P=0.058)$ that the cut-to-length system preserved a greater proportion of large trees than the full-tree system. The cut-to-length system conserved more (in both absolute and relative terms) small trees $(<10 \mathrm{~cm} \mathrm{DBH})$ than did the full-tree system. The difference in proportion preserved was more pronounced in the summer harvest than in winter. For small and large trees combined, preservation of stems by the cut-to-length system was significantly greater than by the full-tree system. With the cut-to-length system, $58-60 \%$ of the stems $>1.3 \mathrm{~m}$ tall remained after harvest, compared with $22-34 \%$ for the full-tree system.

The pre-harvest basal area did not differ significantly among the harvest treatments or seasons (Table 2). However, basal area was greater after the cut-to-length harvest than after the full-tree harvest. About $6-9 \%$ of the original basal area remained after full-tree harvesting and $18-19 \%$ remained after the cut-to-length harvest.

There were no significant differences among harvest treatments in pre-harvest total volume (Table 2). Failures in the assumptions did not permit two-way analysis of variance of pre-harvest merchantable volume, but the Mann-Whitney U test indicated no differences between harvest methods or seasons $(P=0.584$ and 1.000 , respectively). Post-harvest total volume was significantly greater with the cut-to-length system than with the full-tree harvest, and there was strong evidence $(P=0.063)$ that post-harvest merchantable volume was also greater.
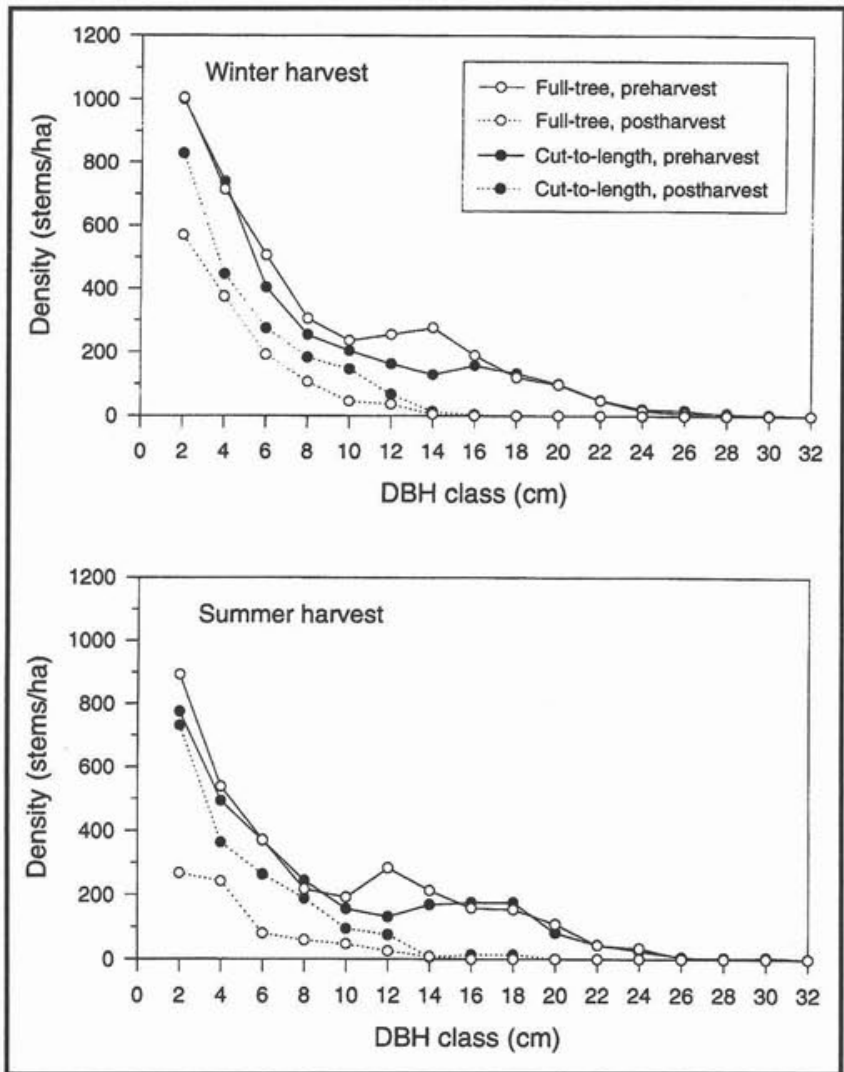

Fig. 1. Pre and post-harvest diameter distribution (all conifer species) for the full-tree and cut-to-length comparison (data points are positioned at the upper diameter of the 2-cm diameter range).

\section{Residual trees $<1.3 \mathrm{~m}$ Tall}

Failures in the assumptions did not permit two-way analysis of variance of pre-harvest density of black spruce stems $<1.3 \mathrm{~m}$ in height, but the Mann-Whitney U test indicated that it was significantly greater $(P=0.006)$ in the winter harvest blocks than in the summer blocks (Table 3). This significant difference persisted after harvest, and the ratio of post-harvest to preharvest density also showed evidence $(P=0.062)$ of difference between seasons. The post-harvest to pre-harvest density ratio was significantly greater with the cut-to-length system than with the full-tree system, and this difference was more pronounced in the summer than in the winter.

Pre-harvest stocking of black spruce stems $<1.3 \mathrm{~m}$ tall did not vary significantly among treatments (Table 3 ). Postharvest stocking was significantly higher in the winter harvest $(80-81 \%)$ than in the summer harvest (55-70\%). The ratio of post-harvest to pre-harvest stocking differed significantly between harvest systems $(P=0.032)$ and between seasons $(P=0.008)$. Cut-to-length harvesting resulted in a greater ratio of post-harvest to pre-harvest stocking than did the full-tree system.

\section{Damage to Residuals $>1.3 \mathrm{~m}$ Tall}

Both harvest system and season had significant effects on the percentage of black spruce residuals that were undamaged (Table 4). The cut-to-length system left $72 \%$ of the residuals undamaged in the winter, and $89 \%$ in the summer. The percentages of undamaged residuals remaining after the full-tree 
Table 1. Density (stems ha ${ }^{-1}$ ) of all conifer species (stems $>1.3 \mathrm{~m}$ tall) prior to and one growing season after harvesting

\begin{tabular}{|c|c|c|c|c|c|c|c|c|c|}
\hline & \multicolumn{3}{|c|}{$\leq 10 \mathrm{~cm} \mathrm{Dbh}$} & \multicolumn{3}{|c|}{$>10 \mathrm{~cm} \mathrm{Dbh}$} & \multicolumn{3}{|c|}{ All stems } \\
\hline & Pre-harvest & Post-harvest & Ratio & Pre-harvest. & Post-harvest & Ratio & Pre-harvest & Post-harvest & Ratio \\
\hline \multicolumn{10}{|l|}{ Winter } \\
\hline Full-tree & 2,767 & 1,288 & 0.45 & 1,021 & 42 & 0.044 & 3,788 & 1,329 & 0.337 \\
\hline Cut-to-length & 2,600 & 1,879 & 0.72 & 779 & 83 & 0.110 & 3,379 & 1,963 & 0.580 \\
\hline \multicolumn{10}{|l|}{ Summer } \\
\hline Full-tree & 2,209 & 692 & 0.32 & 1,000 & 34 & 0.033 & 3,209 & 726 & 0.224 \\
\hline Cut-to-length & 2,039 & 1,638 & 0.80 & 813 & 107 & 0.133 & 2,851 & 1,745 & 0.595 \\
\hline $\begin{array}{l}\text { Probability of harvest type } \\
\text { exceeding } F \text { in ANOVA }\end{array}$ & 0.704 & $0.032^{*}$ & $<0.001^{* *}$ & $0.028^{*}$ & 0.113 & 0.058 & 0.360 & $0.034^{*}$ & $<0.001^{* * \mathrm{~S}}$ \\
\hline $\begin{array}{l}\text { Probability of season } \\
\text { exceeding } F \text { in ANOVA }\end{array}$ & 0.230 & 0.189 & 0.345 & 0.934 & 0.812 & 0.882 & 0.200 & 0.234 & $0.590^{\mathrm{S}}$ \\
\hline $\begin{array}{l}\text { Probability of interaction } \\
\text { exceeding } F \text { in ANOVA }\end{array}$ & 0.997 & 0.558 & $0.006^{* *}$ & 0.736 & 0.633 & 0.652 & 0.951 & 0.560 & $0.319^{\mathrm{S}}$ \\
\hline
\end{tabular}

"Significant difference at $\alpha=0.05$

${ }^{* *}$ Significant difference at $\alpha=0.01$

$\mathrm{S}_{\text {ANOVA carried out on transformed }\left(x^{2}\right) \text { data. }}$

Table 2. Basal area, total and merchantable volume of all conifer species prior to and one growing season after harvesting

\begin{tabular}{|c|c|c|c|c|c|c|c|c|c|}
\hline & \multicolumn{3}{|c|}{ Basal area $\left(\mathrm{m}^{3} \mathrm{ha}^{-1}\right)$} & \multicolumn{3}{|c|}{ Total volume $\left(\mathrm{m}^{3} \mathrm{ha}^{-1}\right)$} & \multicolumn{3}{|c|}{ Merchantable volume $\left(\mathrm{m}^{3} \mathrm{ha}^{-1}\right)$} \\
\hline & Pre-harvest & Post-harvest & Ratio & Pre-harvest & Post-harvest & Ratio & Pre-harvest & Post-harvest & Ratio \\
\hline \multicolumn{10}{|l|}{ Winter } \\
\hline Full-tree & 22.60 & 1.80 & 0.09 & 126.45 & 4.91 & 0.05 & 108.45 & 1.70 & 0.02 \\
\hline Cut-to-length & 19.63 & 3.46 & 0.19 & 115.03 & 11.06 & 0.11 & 99.86 & 4.36 & 0.05 \\
\hline \multicolumn{10}{|l|}{ Summer } \\
\hline Full-tree & 21.69 & 1.21 & 0.06 & 126.44 & 3.86 & 0.03 & 111.40 & 1.61 & 0.01 \\
\hline Cut-to-length & 19.32 & 3.47 & 0.18 & 114.10 & 12.47 & 0.11 & 100.29 & 6.43 & 0.07 \\
\hline $\begin{array}{l}\text { Probability of harvest type } \\
\text { exceeding } F \text { in ANOVA }\end{array}$ & $0.237^{\mathrm{S}}$ & $0.043^{*}$ & $0.041^{*}$ & $0.500^{\mathrm{L}}$ & $0.039^{*}$ & 0.068 & & 0.063 & $0.051^{R}$ \\
\hline $\begin{array}{l}\text { Probability of season } \\
\text { exceeding } F \text { in ANOVA }\end{array}$ & $0.644^{S}$ & 0.729 & 0.685 & $0.846^{\mathrm{L}}$ & 0.952 & 0.855 & & 0.578 & $0.467^{\mathrm{R}}$ \\
\hline $\begin{array}{l}\text { Probability of interaction } \\
\text { exceeding } F \text { in ANOVA }\end{array}$ & $0.926^{\mathrm{S}}$ & 0.716 & 0.799 & $0.958^{\mathrm{L}}$ & 0.687 & 0.751 & & 0.546 & $0.837^{R}$ \\
\hline
\end{tabular}

significant difference at $\alpha=0.05$.

SANOVA carried out on transformed $\left(x^{2}\right)$ data.

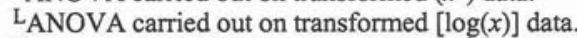

${ }^{\mathrm{R}}$ ANOVA carried out on transformed $\left(x^{0.5}\right)$ data.

harvest were $57 \%$ in winter and $65 \%$ in summer. Among damage categories, harvest effects were significant only for the broken top/stem category, with more damage occurring in the full-tree system. During the winter harvest, broken top/stem (13\%) and sheared branches $(12 \%)$ were the most frequent damage conditions with the full-tree system. With the cut-to-length system, sheared branches accounted for the highest proportion $(10 \%)$ of damage in the winter; in the summer, no one type of damage predominated. In the full-tree summer harvests, the broken stem/top category occurred the most frequently ( $11 \%)$.

\section{Site Disturbance}

Season of harvest had significant effects on both shallow and deep rutting (Table 5), with more rutting in the summer than in the winter.

\section{Full-tree and Tree-length Comparison}

There was very little difference in the post-harvest characteristics of residuals and regeneration between the fulltree and the tree-length systems (Table 6). Only the post-harvest to pre-harvest ratio of the density of total stems (>1.3 m in height) differed significantly with $40 \%$ of the total stems remaining after harvest with the full-tree system, and $45 \%$ with the tree-length.

\section{Discussion}

Differences in advance growth protection between the full-tree and tree-length harvest systems were minor, supporting another comparative study in balsam fir forests (Cormier et al. 1993). Ruel (1992), however, observed that full-tree harvesting with a feller-forwarder resulted in greater softwood stocking than tree-length operations. In the current study, both the full-tree and the tree-length systems used a feller-buncher, resulting in similar trail width and spacing. The feller-buncher used in the tree-length system was somewhat better at preserving advance growth and residuals than the one used in full-tree system, because the tail of the cab did not swing beyond the tracks, and because the harvesting head was slightly more manoeuvrable. However, the grapple skidder used in this system required more room to turn around, and this caused widening of the trails. Thus, with similar advance growth protection, the main factor in choosing between these systems is cost. Harvesting costs are substantially lower with the full-tree 


\begin{tabular}{|c|c|c|c|c|c|c|}
\hline & \multicolumn{3}{|c|}{ Density (stems ha-1) } & \multicolumn{3}{|c|}{ Stocking ( $\%, 4 \mathrm{~m}^{2}$ basis) } \\
\hline & Pre-harvest & Post-harvest & Ratio & Pre-harvest & Post-harvest & Ratio \\
\hline \multicolumn{7}{|l|}{ Winter } \\
\hline Full-tree & 34,394 & 13,535 & 0.39 & 91 & 80 & 0.88 \\
\hline Cut-to-length & 30,325 & 12,679 & 0.42 & 90 & 81 & 0.90 \\
\hline \multicolumn{7}{|l|}{ Summer } \\
\hline Full-tree & 20,759 & 6,792 & 0.32 & 86 & 55 & 0.64 \\
\hline Cut-to-length & 20,813 & 11,726 & 0.56 & 84 & 70 & 0.83 \\
\hline $\begin{array}{l}\text { Probability of harvest type } \\
\text { exceeding } F \text { in ANOVA }\end{array}$ & & 0.219 & $0.001^{* * \mathrm{~S}}$ & 0.665 & 0.196 & $0.032^{*}$ \\
\hline $\begin{array}{l}\text { Probability of season } \\
\text { exceeding } F \text { in ANOVA }\end{array}$ & & $0.038^{*}$ & $0.062^{\mathrm{S}}$ & 0.204 & $0.015^{*}$ & $0.008^{* *}$ \\
\hline $\begin{array}{l}\text { Probability of interaction } \\
\text { exceeding } F \text { in ANOVA }\end{array}$ & & 0.097 & $0.004^{* \mathrm{~S}}$ & 0.931 & 0.250 & 0.079 \\
\hline
\end{tabular}

significant difference at $\alpha=0.05$.

** significant difference at $\alpha=0.01$.

SANOVA carried out on transformed $\left(x^{2}\right)$ data.

Table 4. Condition of black spruce residuals (stems $>1.3 \mathrm{~m}$ in height) one growing season after harvesting (percent)

\begin{tabular}{|c|c|c|c|c|c|c|}
\hline & Undamaged & $\begin{array}{l}\text { Broken } \\
\text { stem / top }\end{array}$ & $\begin{array}{l}\text { Sheared } \\
\text { branches }\end{array}$ & $\begin{array}{l}\text { Scraped } \\
\text { stems }\end{array}$ & $\begin{array}{c}\text { Sun } \\
\text { scorched }\end{array}$ & $\begin{array}{c}\text { Multiple } \\
\text { damage }\end{array}$ \\
\hline \multicolumn{7}{|l|}{ Winter } \\
\hline Full-tree & 57.29 & 12.76 & 12.36 & 2.08 & 3.17 & 12.34 \\
\hline Cut-to-length & 71.86 & 4.65 & 10.36 & 4.66 & 2.22 & 6.24 \\
\hline \multicolumn{7}{|l|}{ Summer } \\
\hline Full-tree & 65.27 & 11.46 & 5.76 & 3.53 & 3.61 & 10.37 \\
\hline Cut-to-length & 88.69 & 3.86 & 2.98 & 2.10 & 0.30 & 2.06 \\
\hline $\begin{array}{l}\text { Probability of harvest type } \\
\text { exceeding } F \text { in ANOVA }\end{array}$ & $0.008^{* *} \mathrm{~L}$ & $0.011^{* L}$ & 0.557 & $0.692^{\mathrm{R}}$ & 0.235 & 0.090 \\
\hline $\begin{array}{l}\text { Probability of season } \\
\text { exceeding } F \text { in ANOVA }\end{array}$ & $0.048^{* L}$ & $0.623^{\mathrm{L}}$ & 0.114 & $0.979^{\mathrm{R}}$ & 0.664 & 0.429 \\
\hline $\begin{array}{l}\text { Probability of interaction } \\
\text { exceeding } F \text { in ANOVA }\end{array}$ & $0.636^{\mathrm{L}}$ & $0.949^{\mathrm{L}}$ & 0.923 & $0.583^{R}$ & 0.496 & 0.771 \\
\hline
\end{tabular}

Significant difference at_ $=0.05$.

"Significant difference at ${ }_{-}=0.01$.

LANOVA carried out on transformed $[\log (\mathrm{x})]$ data.

${ }^{R}$ ANOVA carried out on transformed $\left(x^{0.5}\right)$ data.

system (Cormier et al. 1993), accounting for its widespread use.

The full-tree and tree-length systems differ in the removal of foliage, small branches and nutrients, from the site. For example, full-tree systems in upland black spruce removed $400 \%$ more $\mathrm{N}$ and $60 \%$ more $\mathrm{Ca}$ than did tree-length systems (Foster and Morrison 1987). However, the consequences of these differing removals on the long-term productivity of peatland sites have received little attention, but are currently being studied in the Lake Abitibi Model Forest.

The cut-to-length system and the full-tree system differed in a number of ways. The cut-to-length system left more residual trees (both $>1.3 \mathrm{~m}$ tall and $<1.3 \mathrm{~m}$ tall), especially in summer. The cut-to-length system also caused less site disturbance during summer harvesting and less damage to residual trees. The differences in regeneration and disturbance observed here are in agreement with results from a comparison of fulltree and cut-to-length systems in jack pine and mixedwood stands (Gingras 1994).

The differences in the effects between the two systems can be attributed mainly to equipment characteristics. The harvester in the cut-to-length system had a greater reach (nearly $9 \mathrm{~m}$ ) than the feller-buncher, and the cut-to-length equipment was
Table 5. Cover (percent) of site disturbance one growing season after harvesting. The Mann-Whitney $\mathrm{U}$ test was used to detect differences

\begin{tabular}{|c|c|c|}
\hline & $\begin{array}{l}\text { Shallow } \\
\text { Ruts }\end{array}$ & $\begin{array}{l}\text { Deep } \\
\text { Ruts }\end{array}$ \\
\hline \multicolumn{3}{|l|}{ Winter } \\
\hline Full-tree & 8 & $<0.001$ \\
\hline Cut-to-length & 6 & 0 \\
\hline \multicolumn{3}{|l|}{ Summer } \\
\hline Full-tree & 28 & 14 \\
\hline Cut-to-length & 11 & 8 \\
\hline $\begin{array}{l}\text { Probability of difference } \\
\text { between harvest methods }\end{array}$ & 0.100 & 0.447 \\
\hline $\begin{array}{l}\text { Probability of difference } \\
\text { between seasons }\end{array}$ & $0.006^{* *}$ & $0.004^{* *}$ \\
\hline
\end{tabular}

"Significant difference at $\alpha=0.05$

*"Significant difference at $\alpha=0.01$

narrower than the equipment used in the full-tree system. As a result the trails in the cut-to-length system were narrower and more widely spaced. In addition, the harvesting head in the cutto-length system was smaller and more manoeuvrable than the feller-buncher head, resulting in better retention of trees and less damage to residuals between trails. 


\begin{tabular}{|c|c|c|c|}
\hline & \multicolumn{2}{|c|}{ Harvest system } & \multirow{2}{*}{$\begin{array}{c}\text { Probability of exceeding } \\
t \text { in paired } t \text {-test }\end{array}$} \\
\hline & Full-tree & Tree-length & \\
\hline $\begin{array}{l}\text { Density }\left(\text { stems ha } \mathrm{h}^{-1}\right) \\
>1.3 \mathrm{~m} \text { tall, } \leq 10 \mathrm{~cm} \mathrm{Dbh} \\
>10 \mathrm{~cm} \mathrm{Dbh} \\
\text { All stems }\end{array}$ & $\begin{array}{r}1,500 \\
125 \\
1,625\end{array}$ & $\begin{array}{r}1,175 \\
325 \\
1,410\end{array}$ & $\begin{array}{l}0.184 \\
0.143 \\
0.342\end{array}$ \\
\hline $\begin{array}{l}\text { Post-harvest to pre-harvest ratio } \\
\text { for all stems }\end{array}$ & 0.40 & 0.45 & $0.032^{*}$ \\
\hline Basal area $\left(\mathrm{m}^{2} \mathrm{ha}^{-1}\right)$ & 3.44 & 5.01 & 0.160 \\
\hline Post-harvest to pre-harvest ratio & 0.16 & 0.31 & 0.178 \\
\hline Merchantable volume $\left(\mathrm{m}^{3} \mathrm{ha}^{-1}\right)$ & 8.28 & 19.42 & 0.120 \\
\hline Post-harvest to pre-harvest ratio & 0.09 & 0.26 & 0.199 \\
\hline $\begin{array}{l}\text { Black spruce }<1.3 \mathrm{~m} \text { tall } \\
\text { Density }\left(\text { stems ha }{ }^{-1}\right)\end{array}$ & 6,965 & 5,540 & 0.240 \\
\hline Post-harvest to pre-harvest ratio & 0.52 & 0.40 & 0.127 \\
\hline Stocking $\left(\%, 4 \mathrm{~m}^{2}\right.$ basis $)$ & 59 & 53 & 0.466 \\
\hline Post-harvest to pre-harvest ratio & 0.78 & 0.71 & 0.265 \\
\hline
\end{tabular}

"Significant difference at $\alpha=0.05$.

The incidence of damage to trees in the cut-to-length harvest was comparable to a similar study with the cut-to-length system, done during the same winter (MacDonell and Groot 1996). The high percentage of damaged trees in the winter, especially with sheared branches, could be related to the extreme conditions, with temperatures averaging -35 to $-40^{\circ} \mathrm{C}$ by day. At these temperatures, trees are brittle and susceptible to breakage when struck by equipment or felled trees. During the summer harvest, the difference in damage percentages, particularly broken stems and tops, was a result of equipment operation. The full-tree system required straight trails, passing through any patches of non-merchantable stems. Conversely, the cutto-length equipment was more flexible, travelling around patches of advance growth. With all harvesting systems, increased attention to protection by operators in both the harvesting and forwarding phases could result in higher stocking of undamaged advance growth and residuals.

Choosing between the cut-to-length and full-tree systems for peatland black spruce requires balancing harvesting cost with post-harvest stand structure and associated forest values. Because the single-grip harvester processes only one tree at time, harvest costs for the cut-to-length system increase rapidly as mean tree size decreases (Gingras 1994; Plamondon 1995). Black spruce trees on peatlands are typically small, and harvesting costs for full-tree systems are lower than for cutto-length systems.

The cost advantage of the full-tree system is likely to be decisive in areas where advance growth is abundant, as it was in this study. However, when pre-harvest levels of advance growth are moderate, the superior protection of advance growth offered by the cut-to-length system may be required to achieve satisfactory stocking, particularly in summer. Also, the much greater retention of non-merchantable residuals by the cut-to-length system will likely translate into a reduction of rotation length. Stands with the tallest post-harvest residuals produce the largest yields for a given site quality and numbers of years after release (Pothier et al. 1995) but, more research is required to examine how the quantity, size and distribution of advance growth affect future yields. Forecasts of stand growth and development were completed as part of this project, and should aid in choosing between systems.

As in the tree-length system, the cut-to-length system retains more nutrients on site. If concerns about long-term productivity emerge for peatlands, this may become an additional factor to consider in choosing between systems.

The effectiveness of these harvesting systems in protecting stems $<1.3 \mathrm{~m}$ tall is generally comparable with previous studies. The ratio of postharvest to preharvest stocking of stems $<1.3 \mathrm{~m}$ tall averaged 0.82 for all of the winter operations, although the ratio was considerably greater in the cut-to-length versus full-tree comparison than in the tree-length versus full-tree comparison. This difference may have been caused by lower snow depths during the late winter harvest in the latter comparison. Groot (1995) also observed a ratio of 0.82 for a winter full-tree harvesting system near Kapuskasing, Ontario. The ratio of postharvest to preharvest stocking for summer fulltree harvesting in this study $(0.64)$ lies midway between the values observed by Groot (1995) for summer full-tree harvesting using wide-tired skidders $(0.69)$ and summer tree-length harvesting using manual felling and narrow-tired skidders $(0.62)$. The ratio for the cut-to-length system in summer (0.83), substantially exceeds those for other harvesting systems in summer.

Harvesting with regeneration protection for black spruce on peatlands will generally create stands with an uneven size structure. These stands will likely resemble the stands that developed following the hand-felling and horse-skidding operations in the first half of the century (Groot and Horton 1994). This study suggests that stands developing following summer full-tree harvest might be an exception to this generalization, since the postharvest reverse-J diameter distribution was less prominent for this treatment.

\section{Conclusions}

In winter, the protection of stems $<1.3 \mathrm{~m}$ tall provided by the cut-to-length and tree-length systems was similar to that 
provided by the full-tree system. However, the cut-to-length harvest was more effective in protecting stems $<1.3 \mathrm{~m}$ tall in the summer, and in protecting stems $>1.3 \mathrm{~m}$ tall in both the summer and winter. This system also produced less site disturbance in summer operations. These advantages of the cut-to-length system must be weighed against its higher harvesting costs in peatland black spruce. The cut-to-length method would be ideal for more sensitive sites where minimal impact is needed, and in areas with moderate levels of advance growth, to maximize the potential for natural regeneration.

The tree-length and full-tree systems provide similar levels of advance growth protection, and lower harvesting costs will continue to favour the use of the full-tree system for peatland black spruce. The effects of nutrient removal may become an additional factor to consider when comparing these two systems.

These harvesting systems when conducted with the objective of protecting black spruce advance growth, will produce forests with an uneven-sized structure, similar to those that arose after manual logging in the first half of the century.

\section{Acknowledgements}

This study was funded through the Lake Abitibi Model Forest. Thanks are due to the woodlands staff, particularly Rod Gemmell, of Abitibi-Price Inc. (API) of Iroquois Falls for their help in carrying out this project. We would also like to thank the many forestry students who carried out assessments, and Mike Adams for his advice and technical assistance throughout the trials. Special thanks are extended to Ben Gagnon and Benoît Dubé, owner-operators of the Timberjack FMG machinery, for their great patience and cooperation with the timber harvesting and training of API operators. Finally, we would like to thank Rob Fleming and Jean-Claude Ruel for constructive reviews of the paper.

\section{References}

Cormier, D., P. Meek, J. Favreau and J.-F. Gingras. 1993. Comparative analysis of full-tree and tree-length harvesting systems in Western Newfoundland. Forestry Canada, Nfld. and Labrador Region. St. John's, NF. FPD Rep. 68. 34 p.

Foster, N.W. and I.K. Morrison. 1987. Alternate strip clear-cutting in upland black spruce IV. Projected nutrient removals associated with harvesting. For. Chron. 63: 451-456.

Frisque, G., G.F. Weetman and E. Clemmer. 1978. Reproduction and trial projected yields 10 years after cutting 36 pulpwood stands in eastern Canada. For. Eng. Res. Inst. Can. (FERIC), Vancouver, BC. FERIC Tech. Rep. TR-23. 63 p.
Gingras, J.-F. 1990. Les méthodes d'exploitation favorisant la protection de la régénération: l'éxperience du Québec. Inst. Can. Rech. en Génie, Pointe-Claire, Qué. For. Fiche Technique FT-144. 8 p.

Gingras, J.-F. 1991. Cut-to-length system provides the best protection for regeneration. Can. For. Ind. June/July: 10-13.

Gingras, J.-F. 1994. A comparison of full-tree versus cut-to-length systems in the Manitoba Model Forest. For. Eng. Res. Inst. Can. (FERIC), Pointe-Claire, Que. Special Rep. SR-92. 16 p.

Groot, A. 1984. Stand and site conditions associated with abundance of black spruce advance growth in the Northern Clay Section of Ontario. Can. Dep. Environ., Can. For. Serv., Sault Ste Marie, ON., Inf. Rep. O-X-358. 20 p.

Groot, A. 1995. Harvesting method affects survival of black spruce advance growth.North. J. Appl. For. 12(1): 8-11.

Groot, A. and Horton, B.J. 1994. Age and size structure of natural and second-growth peatland Picea mariana stands. Can. J. For. Res. 24: $225-233$.

Hintze, J.L. 1995. NCSS 6.0 statistical system for Windows. Number Cruncher statistical Systems. Kaysville, UT. 777 p.

Honer, T.G., M.F. Ker and I.S. Alemdag. 1983. Metric timber tables for the commercial tree species of central and eastern Canada. Can. Dep. Environ., Can. For. Serv., Fredericton, NB. Inf. Rep. M-X-140. $139 \mathrm{p}$.

Jeglum, J.K., V.F. Haavisto and A. Groot. 1983. Peatland forestry in Ontario. p. 127-167 In A symposium on peat and peatlands, J.D. Sheppard, J. Musial and T. E. Tibbetts, T.E. (eds.). 12-15 September 1982. Shippagan, New Brunswick. Energy, Mines and Resources. Halifax, NS. 582 p.

MacDonell, M.R. and Groot, A. 1996. Uneven-aged silviculture for peatland second-growth black spruce: biological feasibility. Nat. Resour. Can., Canadian Forest Service, Great Lakes Forestry Centre, Sault Ste Marie, ON. NODA Rep. TR-36. 14 p.

McCarthy, T.G., R.W. Arnup, J. Nieppola, B.G. Merchant, K.C. Taylor and W.J. Parton. 1994. Field guide to forest ecosystems of Northeastern Ontario. Northeast Science and Technology, Ont. Min. of Nat. Resour. Timmins, ON. NEST Field Guide FG-001. $161 \mathrm{p}$.

Maurer, N.L. 1993. Deriving local tree volume information. Northeast Science and Technology, Ont. Min. of Nat. Resour., Timmins, ON. NEST Tech. Rep. TR-010. 42 p.

Plamondon, J.A. 1995. Productivity and cost of a shortwood system in partial cutting of black spruce. For. Eng. Res. Inst. Can. (FERIC), Pointe-Claire, PQ. Field Note: Partial Cutting - 7

Pothier, D., R. Doucet and J. Boily. 1995. The effect of advance regeneration height on future yield of black spruce stands. Can. J. For. Res. 25: 536-544.

Rowe, J.S. 1972. Forest Regions of Canada. Can. For. Serv. Publ. 1300. Ruel, J.-C. 1992. Abondance de la régénération 5 ans après la coupe à blanc mécanisée de peuplements d'épinette noire (Picea mariana). Can. J. For. Res. 22: 1630-1638. 